\title{
Faith Healing Revisited: A Charismatic Christian Intervention to the Therapy Culture in Finland
}

\section{Tuija Hovi}

Healing with the help of the Holy Spirit has traditionally been a pivotal theme in Pentecostal and Charismatic churches throughout the world. In recent decades, Pentecostalism in its various forms has rapidly expanded globally, raising interest and gaining more adherents, especially in Latin America, Asia, and Africa, though it still has a firm foothold in the Western world (see e.g., Anderson 2004). This expansion on every continent has been largely interpreted as a result of the cultural adaptability of Pentecostalism, especially of its doctrinal message, which focuses on healing. For instance, Candy Gunther Brown points out that the recognized limits of scientific biomedicine fuel therapeutic experimentation with divine healing, as they do with other alternative remedies, many of which invoke aid from personal or impersonal spiritual sources (Brown 2011, 8). Healing in diverse Pentecostal contexts is not understood only in medical terms but also in a more holistic way including, if not even requiring, an individual's personal spiritual transformation. Especially among the Third Wave Charismatics, the holistic understanding of healing also covers "this-worldly" material well-being. For this reason, the branch in question

\section{T. Hovi $(\bowtie)$}

University of Turku, Turku, Finland

(C) The Author(s) 2018

J. Moberg, J. Skjoldli (eds.), Charismatic Christianity in Finland, Norway, and Sweden, Palgrave Studies in New Religions and Alternative Spiritualities, https://doi.org/10.1007/978-3-319-69614-0_7 
has been branded the Health and Wealth Gospel or Prosperity Theology by adherents of the established churches, as well as by Classic Pentecostals (cf. Brown 2011, 10). ${ }^{1}$

In the study of Christianity, the term "faith healing" is sometimes seen as ridiculing and pejorative. Brown, for her part, chooses "divine healing" instead, accepting the definition of the practitioners themselves, who wish to emphasize God's love instead of merely human faith or an impersonal spiritual force as a source of healing (Brown 2011, 4-5.) Nevertheless, without deliberately giving any value-laden connotations to the terms, I prefer to use "faith healing" as an umbrella term for the above-mentioned healings; that is, for those that are practiced with the help of prayer or other forms of ritual practices, including the notion of being in contact with a superhuman power. With "divine healing" I refer to healing in Christianity generally, whereas "charismatic healing" refers specifically to healing which is understood as a result of the gifts of the Holy Spirit (i.e. "charisms").

In this chapter, I focus on the relationships between well-being and religion in the context of the Christian intercessory prayer service called the Healing Rooms in present-day Finland. ${ }^{2}$ The Healing Rooms (HR) concept was developed in its contemporary form in the 1990s in the United States, and has thereafter grown into a worldwide lay-based network. The underlying purpose of HR activity is evangelization and preparing people for the apocalyptic "end times," and to "save" as many as possible by awakening them to spiritual growth as Christian believers. However, this mission is not implemented by preaching, as is usually done in congregations and at revival meetings. Instead, it is carried out only implicitly by praying for people individually and privately, according to their personal requests. Intercessory prayer, as both a communal and private act, is an elementary part of Christian spirituality. The peculiarity of this prayer movement is the way in which the idea of intercession is put into practice: The HR operates at premises called "prayer clinics," giving the impression of spiritual health centers.

The central issue in this analysis concerns how traditional Christian notions and practices of divine healing, especially charismatic healing, fit modern Nordic society, with its highly developed and specialized healthcare system and psychologized therapy culture. I also explore how the international, originally American, HR has been accommodated in the traditionally Lutheran, but today rather secularized Finnish culture, and discuss how this interdenominational, lay-based organization defines and justifies its position in the country's religious landscape. 
I begin with a short overview of the Christian scene in Finland to provide a backdrop to the context in which the HR operates. Thereafter, I move on to discuss the psychologization of culture and how it has been adopted by the national Christian scene, which comprises the context for my analysis. Next, I introduce the HR with a brief summary of its history and the basic idea of the practice, as well as the empirical material of the study. The description of the setting and procedure at the prayer clinics precedes the discussion on faith healing as an intervention to therapy culture. By the term "therapy culture," I mean the whole range of more or less psychologized, semi-professional practices that aim at creating better coping strategies for a more balanced, successful, and healthy life.

\section{The Christian Scene in Contemporary Finland}

In order to contextualize alternative and interdenominational or independent Christian practices, such as the HR, it is useful to employ a postsecular framework. This calls into perspective several factors that are helpful for understanding the HR's emergence: the resurgence of religion in the public sphere; the fragmentation of the religious landscape; and individualization, in terms of emphasis on personal needs. These processes have been recognized by Jürgen Habermas and many other scholars studying contemporary societies and the role of religion and spirituality in them (Habermas 2006; see also Bahram 2013; Moberg et al. 2012). What further characterizes religious life in contemporary Finland is increasing competition between traditional religious alternatives and other spiritual supply including westernized meditation and yoga pracices as well as New Age oriented energy healing and angel therapy, just to mention a few examples. This development intertwines with questions such as the complex relations between individualism and collectivism, and the various themes of believing, practicing, and belonging. Moreover, the boundaries of several sectors of knowledge, previously treated as juxtaposed-such as scientific, religious, esoteric, and knowledge of therapeutic discourses and practices_are blurring (cf. Utriainen et al. 2012).

The Christian scene in Finland is predominantly Protestant. The Catholic Church (ca. 12,000 members) and the Orthodox Church (ca. 60,000 members) have recently increased their membership numbers, mainly because of immigration, but their rates are still rather modest compared to the mainline church. Most Finns are members of the Evangelical Lutheran Church of Finland (ELC). At the end of 2016, the membership rate was 71.9 percent of a population of nearly 5.5 million inhabitants (ELC 2017). Actual participation in church activities, however, is considerably lower. 
According to the latest quadrennial report of the ELC, based on data collected in 2012-2015, approximately 37 percent of church members participated in services at least once a year, Christmas Eve being the most popular liturgical occasion (ELC 2017; cf. Palmu et al. 2015,93). Over the present decade, the membership rate of the ELC has gradually decreased. Nevertheless, the ELC still dominates the religious landscape. Even though it is not an institutional state church, it nevertheless plays a visible role in the country (cf. Nynäs et al. 2015, 15-16). ${ }^{3}$ Contributing to society, it provides social welfare in the form of diaconal work, maintenance of cemeteries, and international humanitarian aid. The role of the ELC is also important in public debates, where its opinions are, on the one hand, often sought, but on the other, are also criticized. Today, the inclusive and multidimensional character of the ELC is visible also in that it is home to five Pietist-inspired revival-based movements: the Laestadians, the Awakened, the Evangelicals, the Beseechers, and Evangelical Neo-Pietism, or the Fifth Movement, as the last one is usually called in Finland. In addition, the more recent Charismatic Renewal and the Taizé-inspired Friends of Silence are nowadays active within the ELC.

Despite the ELC's dominant role and the solid tradition of old Pietist revival movements, one also finds various Charismatic Christian communities in the country. Pentecostalism was introduced in Finland during the first decade of the twentieth century, and is today the third largest religious group in the country. With approximately 46,000 members, the classic, lay-based, Pentecostal Movement is the largest revival movement outside the ELC, including 238 Finnish-speaking and 26 Swedish-speaking congregations. At present, 48 of the Finnish-speaking congregations are organized under the umbrella organization The Pentecostal Church of Finland (PCF), founded in 2002. The rest are independent and locally organized as registered associations. Despite such organizational division, the classic Pentecostal Movement is quite homogenous (ELC 2017; Ketola 2007, 34-35; PCF 2017; PingstFi 2017).

The Evangelical Free Church of Finland (EFCF), for its part, is a Finnish revival movement, which combines elements of Evangelical theology and Charismatic Christian practices. Historically, it was inspired by the American Holiness Movement of the nineteenth century, which was introduced to Finland through Sweden. The EFCF has been operating in Finland for over 120 years. This denomination consists of 100 local congregations around the country in Finland and one in Spain (EFCF 2017). Other denominations originated in the nineteenth century or earlier, but remain of minor significance to the Christian landscape; their growth leveled out 
quite some time ago. By contrast, the rapid growth of new independent congregations, from the 1980s onwards, has been notable. These communities mostly represent Third Wave Charismatic Christianity. The number of these congregations is currently estimated to be over 100. However, the instability and mobility in the Charismatic scene makes it very difficult to give exact figures (Hovi 2009; Ketola 2007).

In sum, it is hardly appropriate to call Charismatic Christianity a single "movement," classified in terms of the sociological church/sect typology, considering all its global diversity both inside and outside the older churches (cf. Anderson 2010, 13; Beyer 2003, 373). Likewise, in Finland, it is a Christian spiritual trend that exists both inside and outside the ELC. There is, on the one hand, a vibrant congregational field inhabited by numerous independent local communities and evangelizing organizations. On the other hand, the Charismatic Renewal and similar alternative activities are found within the mainline church, albeit to varying degrees of organization and autonomy (Hovi 2009; Hovi and Haapalainen 2015).

\section{Psychologized Discourse and Therapy Culture}

The psychologization of everyday life-including religious life-takes place when ordinary people reflect upon themselves and their environment in accordance with psychological models, without primarily seeing psychology as a scholarly discipline. Psychologization can thus be defined as "psychological vocabulary and psychological explanatory schemes entering fields which are supposed not to belong to the traditional and practical terrains of psychology" (De Vos 2012). The breakthrough of psychologization and therapeutization in Finland is said to have happened with the help of historian Juha Siltala's studies on the anxiety disorder growing out of the Finnish mentality and culture (Siltala 1992) and the masculine conceptions of honor, which focused on the culturally inherited need of the Finnish man to overcome shame through success and achievements (Siltala 1994). In addition to Siltala's psychohistorical interpretations of Finnish mentality, a trilogy of studies on different aspects of "psycho-culture" by sociologist Janne Kivivuori in the 1990s ignited critical discussion on the psychologization of everyday life. According to Kivivuori, by the end of the 1980s, popular psychology had become increasingly visible in many ways, above all in the media, societal debate, commercial life, and everyday conversation in Finland (Kivivuori 1991; Kivivuori 1996). 
Psychological concepts and ideas of emotional and social coping have also been adopted in religious discourses in various parts of the world, particularly in North America. One example is therapeutically inclined Christian counseling. The realms of medical care, psychological therapies, and spiritual coaching overlap in many Christian communities, especially those focusing on healing. Anthropologist Pamela E. Klassen has shown how North American liberal Protestants renewed theologies and pastoral care by combining psychological and Charismatic Christian approaches to the self. According to Klassen, as "diagnosticians of the moral self," such groups combined ideas of faith healing, Charismatic Renewal, and psychology (Klassen 2011, xxii). While she describes the beginning of the Charismatic Renewal among Anglicans, Episcopalians, and Roman Catholics in the United States and Canada in the 1960s, she also points out analogies to what today may be called mindfulness. One example is the "habitual fourfold process," with its focus on holistic healing. This process was employed in preparing Christians for God's healing power. The recommended process included (1) daily relaxation, (2) reminding oneself of life outside oneself, (3) inviting that life to increase in one's own body, (4) visualizing one's body, or for the more advanced, forgetting one's body and, instead, concentrating on the spiritual energies of God (Klassen 2011, 146). Furthermore, instead of seeing the subconscious merely as the site of demonic activity, as suggested earlier by the influential Catholic theologian Paul Tillich, the subconscious came to be regarded as a human resource to be trained and utilized as "a control center under orders of God" (Klassen 2011, 145-146).

Similar tendencies have been noted in studies of pastoral counseling and Christian therapy groups in Finland. Kivivuori recognized the psychologizing trend emerging also in the mainline Lutheran church (Kivivuori 1999), tracing the origins of the psychologized pastoral counseling to the idea of the "surgery of the soul" based upon the Oxford Group Movement of the 1930s and the Moral Re-armament Movement's principles. According to those principles, the criteria for authenticity of an individual's faith are the authenticity and health of his or her personality which can be restored in a close social interaction during pastoral counseling. Moreover, social and often emotional problems can be solved by guiding individuals to convert to the Christian faith (Kivivuori 1999, 67).

In Finland, psychologization discourse has paved the way for contemporary therapy culture and has since become integrated in everyday speech and thinking (Ihanus 2005). Psychological concepts like "searching inside 
oneself," “identity-work," "personal development," "spiritual growth," "self-realization," "depression," "trauma," and "therapy," have become practically self-evident in contemporary public discourse and everyday life. In the Evangelical Lutheran Church in the twentieth century, psychologization became visible, especially in pastoral care and diaconia (i.e. the established charitable work of the ECL), as more elements from psychotherapy were adopted. Gradually, religious discourse in general has absorbed more psychologically framed conceptualizations. For instance, instead of provoking a sense of guilt, psychologically oriented churches prefer to speak of health and authenticity, or of illness or pain instead of sin. One way to update religious life is, indeed, to change one's way of talking about it (cf. Pietikäinen 2000).

In Charismatic Christianity, for its part, its idea of holistic healingcovering physical, emotional, social, and spiritual well-being-makes it obviously easier for its members to adapt to a psychologized culture. A language of, for example, health and authenticity goes hand in hand with the idea of a benevolent God as opposed to a punishing one. Healing Rooms prayer clinics illustrate one way in which such discourse can be operationalized and utilized for purposes of evangelization in contemporary psychologized and postsecular Finnish society.

\section{The Global and Local Healing Rooms}

Third Wave Charismatic Christianity is difficult to categorize into colloquial categories such as "conservative" or "radical," seeing as it combines components traditionally associated with both, even though these labels refer to categories usually perceived as opposites. ${ }^{4}$ In the first place, the acceptance of fundamentalist principles, such as a firm belief in the authority and inerrancy of the Bible, is a component that may be labeled "conservative." The Neo-Charismatic worldview also includes God and Devil as good and evil personified, as well as believing in the existance of evil spirits. At the same time, however, all Charismatics are radical in their view of revelation as continuous, and their expectations of new manifestations of God's power through the Spirit (Chryssides 1999, 123). The latter quality gives space for modernization and new interpretations of sacred text. Furthermore, there is a strong emphasis on individualism, personal growth, and healing, which makes Charismatic Christian healing movements an integral part of the cultural "subjective turn" (cf. Heelas and Woodhead 2005).

This ambivalence is also evident in the Healing Rooms, where biblical fundamentalism is represented in the sense of retaining the "biblical truth," 
as in Pentecostal and Charismatic Christianity. Focusing on the idea of divine healing and the opportunity for lay intercessors to use their personal gifts of the Holy Spirit to help others by mediating divine healing power, the HR promotes salient aspects of Neo-Charismatic thinking. Besides, their international networking, adaptable organization structures, and active use of digital media for advocating their message, link the HR closely to the fluid trend of Neo-Charismatic or Neo-Pentecostal Christianity (cf. Anderson 2010, 19-20). However, it is difficult to categorize the HR merely as a Pentecostal organization, as it operates across denominational boundaries.

The International Association of the Healing Rooms was founded in 2001 , but the origins of this particular prayer service date back to the first decades of the last century. The idea was launched by John Lake, a Pentecostal pastor in Spokane, Washington state. Lake's healing meetings were discontinued soon after his death in 1935 and remained so for several decades. However, his ideas were revived in the 1990s by another Pentecostal pastor, Cal Pierce, who started spreading Lake's ideas by founding local HR prayer clinics, which is the name he gave this type of intercession service. Since then, the HR has spread rapidly to every continent, taking advantage of already existing and functioning local Christian infrastructure, but the headquarters of the movement remain in Spokane. Typically, the prayer clinics operate in churches and congregations.

In Finland, the HR is a newcomer in the religious landscape. It was intentionally imported to Finland and systematically launched by a NeoPentecostal married couple who got to know the prayer clinic service whilst on holiday in California, when they visited a local Vineyard congregation in Santa Barbara. After having negotiated with several pastors and Christian community leaders, they finally founded the first Finnish prayer clinic a year later, following the model of Spokane. Since 2006, 34 prayer clinics have been established around the country (Healing Rooms Finland 2017). In Finland, the HR prayer clinics are, for the most part, connected to classic Pentecostal and EFCF congregations, or to the mainline ELC. Still, a prayer clinic may also be located in nonreligious surroundings like shopping malls, municipal facilities such as club apartments, or in other public premises. Occasionally, prayer clinics are also arranged outdoors, especially during cultural events. In any context, the idea is that a prayer clinic should be accessible to everyone. According to this principle, an HR prayer clinic is never located in an actual church building because of the institutional framing, which may be alienating to many Finns, seeing as church attendance is generally low despite high membership rates. 
The mission of the Finnish HR leaders has been to build cooperative relationships, above all with the ELC, to be able to launch the idea of prayer clinics across the country. Surprisingly, prayer clinics are hardly ever connected to any Neo-Charismatic congregation but only to more established Christian organizations.

Recently, the mission of the Finnish leaders to systematically plant HR further has resulted in a few prayer clinics opening in the neighboring countries Estonia and Sweden. However, there seems to be a greater interest in the HR in Estonia-where seven prayer clinics operate on regular basis-than in Sweden, where only two prayer clinics provide services (Healing Rooms Estonia 2017; Healing Rooms Sweden 2017). In addition, the HR Finnish leaders introduced the HR practice in Norway in 2014. They have also organized several meetings for European HR leaders (Laitinen 2013,4).

\section{Material}

The empirical material was compiled at the turn of 2010 and 2011 by using ethnographic methods, such as interviews and participant observation. I interviewed 30 prayer team members representing five prayer clinics in different districts, including the leading married couple in Espoo, in the headquarters of the Finnish branch. The interviews were semistructured with open-ended questions. The questions revolved around processes of becoming a practitioner and working at prayer clinics. I also asked the interviewees to tell me about their background, their personal motivations, and intentions as intercessors. The discussion with each interviewee took on average 1.5 hours. The oldest of the interviewees was a man born in 1937, and the youngest a man born in 1977. Most were middle-aged or recently retired, born in the 1940s and 1950s. Women make up the majority of the intercessors at the prayer clinics, and of the interviewees; 19 of them were women and 11 men. One third of the interviewees were Pentecostals while the majority were Lutherans. One elderly couple came from the Seventh-day Adventist Church and two from NeoCharismatic congregations, while one local team leader represented the Free Church (EFCF). The age and gender groups as well as religious affiliations of the interviewees correspond quite well with the distribution of prayer team members in general in the Finnish Healing Rooms.

Important contextual information was obtained through participant observation. I visited clinical receptions as a client, naturally informing the 
prayer team members about my research interests. ${ }^{5}$ I was warmly welcomed without any explicitly expressed hesitations concerning my academic intentions. I also visited homes where I interviewed prayer team members, and I received an opportunity to attend a closed meeting of a local prayer team. During my fieldwork, the first Nordic Healing Room conference took place in Helsinki, where I attended the event.

A short questionnaire was also distributed to the visitors at every prayer clinic in the country in May 2011, the number of which was 23 at that time. The purpose of the survey was to provide information on the background and experiences of HR clients. Since the questionnaire was distributed via the prayer clinics, it excluded those clients who had visited a prayer clinic only once and, for one reason or another, did not return. However, the received responses $(\mathrm{N}=124)$ gave an impression of the prayer clinics having both regular and occasional visitors. Most of them74.19 percent-belonged to the mainline ELC, like the majority of Finns. The rest identified as Pentecostals, Free Church members, or Charismatics. It was no big surprise that 78 percent of the respondents participated more or less regularly in Charismatic events, mostly in the context of the ELC. Most of the respondents were women (71 percent). The largest age group was people aged between 36 and 45 years (31.45 percent). Interestingly, few were below 30 or above 60 years of age; both very young and very old were absent. Thus, the HR clientele in the study represent people of working age (see also Hovi 2012).

\section{The Individualized Prayer Service: Setting}

The prayer team members consider the intercession service they provide to be very different than intercessiory prayers in congregational contexts. First of all, HR intercession is completely lay-based. However, it is still highly structured, thoroughly controlled, and carried out only by trained intercessors, unlike the intercessions by priests as a part of Sunday services in congregations. The HR arranges a two-day training course on the principles of the prayer service, which is a prerequisite for becoming a member of a prayer team. The Finnish training package has been created upon the principles of the headquarters in Spokane. The training course consists of learning the "biblical basis" for the intercessory prayer as well as demonstrations and exercises. All prayer team members are required to be committed believers and are expected to be actively involved in their home churches, which has to be proven by a pastor's recommendation. They are also interviewed by 
local team leaders to make sure that they understand and accept the HR rules before they are allowed to start working at a prayer clinic.

Openness and intimacy at $\mathrm{HR}$ clinics were also underlined as significant differences when compared to congregational contexts. The prayer team members emphasized the importance of the low threshold; a client's religious background is not enquired into, the personal intercession is carried out in private, and there is no obligation for action on the part of the client. A male prayer team member in his late thirties described the HR principles and the unique setting at prayer clinics in this way:

Well, there are many [aspects] in it. First of all: this method. It is like the idea that anyone, I mean any Christian believer can be a part of this work. This is not only for pastors or ... or for those who are in charge of certain activities or somehow with a special status in a congregation [...] Anyone can take the training course and come with, anyone who has a vocation for it. And yes, there is the good training for this work, clear ground rules. It guarantees such safety, that even though there are very different persons involved, there are always those rules to be followed, and there are leaders at the clinics [to make sure that they are followed]. It provides safety for this work. And of course, there is a difference also in the way people are provided a very personal prayer service. This does not take place at an altar or in public, but privately so that nobody else can hear what is prayed for. [...] And I can also add that you can come just to be prayed for, there is no need to participate in anything else or listen to a sermon or anything like that. You can come like you go to the doctor's and receive this prayer service. [...] And if I may continue, it is also [the fact] that there is always a team that prays, it also provides a kind of safety, and I believe that it also provides God's presence when there are several people praying. It is actually based on God's word, like "where two or three gather in my name, there am I with them." Jesus put it like this and it's also a good thing. (IF mgt 2011/016: 2) ${ }^{6}$

Before the actual clinical reception opens to clients, the prayer teams prepare by praising and praying by themselves for an hour. This meditative get-together helps them to concentrate on their task and to be present for the clients. The members whom I interviewed regard this preparation time as a necessary step to enable them to take on the role as mediator, to be a "channel" between God and client, as they call themselves. After having done their spiritual preparations, the team members form groups of three intercessors. Serving as a prayer team practitioner does not require any specific outfit. The appearance of intercessors is expected to be casual, clean, and neutral, and they are advised not to use any perfumes because 
of possible allergies. The only visible sign that someone is a team member is a name tag with his or her first name on it.

The local HR clinics are arranged once a week or fortnightly, always at the same time: 18.30-20.30. In the prayer clinic, there is a waiting room where the clients wait for their turn to be prayed for in separate "prayer rooms." While clients wait for their turn, the receptionist gives them a form to fill in. Having written down their prayer requests, they are individually invited into a prayer room, where a team of three members spends 10-20 minutes praying for them, according to their request. The ideal prayer group consists of both men and women. The purpose of this arrangement is to ensure a safe and comfortable atmosphere for everyone. It is said to be ideal that at least one of the prayer team members represents the sex of the person to be prayed for. In addition, it is not desirable that clients either pick and choose certain persons to serve them, or that prayer team members refuse clients on the basis of their sex.

In the course of one clinic session, there are usually on average $10 \mathrm{cli}$ ents and two-to-four groups working for them, depending on the location. The local prayer clinics are not encouraged to prolong the regular reception time of two hours in cases where a large group of people awaits intercession. Instead, the length of each prayer is adapted to the number of clients; the higher the number, the shorter the personal prayer service. Correspondingly, when they are only a few, the intercessions may last longer than 10 minutes. This arrangement is meant to keep the practice controlled and save the energy of the volunteer team members. In case no client appears, team members spend the time praying for each other or some general cause.

\section{The Individualized Prayer Service: Encountering a Client}

At a prayer clinic, two groups of people encounter one another. On the one hand, there is the inner-circle community of carefully selected and trained prayer team members and, on the other, there are clients, people who visit the prayer clinic in order to be prayed for. Even though it is of utmost importance that the prayer team members are "born-again" Christian believers, clients are not required to disclose their religious affiliations or to confess anything unless they wish to. The underlying purpose, however, is to spiritually awaken clients, but only in a way that respects their privacy. During one interview with a female respondent, I asked how 
she would guide a person who checks the "I don't know" box regarding whether she or he is a believer or not. She responded:

Yeah, we may perhaps ask if he or she would like to know more. Nothing like ... we never try to push or impose [...] It is easy to see very quickly if the person is not receptive and then just pass it. But normally, people experience the prayer situation as a good thing, even if they are not at all aware of the things concerning the faith because it is the Holy Spirit that works there. We are, of course, just instruments, we only mediate God's love and his presence and it works in a client in a positive way, praying for another person. (IF mgt 2011/014: 3)

Team members are often reminded by the leaders that the conversation between intercessor and client is meant to be minimal, discreet, and highly confidential. The clients' prayer requests often deal with problems either in their physical, social, or emotional life. Examples may be an illness, a bodily disorder, or depression, but clients also bring up many other kinds of everyday issues, such as domestic problems as well as difficulties in working life, which they wish to be resolved through prayer. All these individual needs and problems are regarded as equally important in relation to a person's spiritual development, and each of them are prayed for in the hope of divine healing (Hovi 2012, 137). It is also explicitly emphasized that the HR service is not intended to replace pastoral counseling, which is regarded as a task that requires professional competence. Praying for various problems is the only service provided at the HR clinics, and in case they have other needs, clients are advised to turn to their home congregations, physicians, or other professionals.

Taking the postsecular culture into consideration, a certain neoliberal and individualist flavor can be sensed in the way the practice is arranged with an emphasized "customer orientation." The prayer team members themselves like to use that expression to highlight their discreet and gentle approach. This approach means that they are allowed to pray only according to the client's request and nothing more. Nor are prayer team members allowed to make a client feel guilty — an approach that differs radically from that of the old Nordic Pietism, as well as from traditional Pentecostalism. However, since spreading the Word and gaining new followers for Jesus is the underlying purpose, conversion is often incorporated as an implicit wish in a prayer for the Holy Spirit to "touch" clients also spiritually while healing their bodily disorders. According to the prayer team members, holistic well-being must include a Christian way of life; any transformation promoting that is interpreted as healing (e.g. Hovi 2013, 201). 
The leading couple of the Finnish HR accentuated the importance of cultural sensitivity in launching the practice successfully. According to them, the setting of the prayer clinic has intentionally been arranged to fit the Finnish reserved mentality as well as the Lutheran culture. A client must be treated in a calm and discreet manner, so for instance, praying in tongues is not allowed in the presence of a client, because it may make him or her feel uneasy. Needless to say, glossolalia is not included in the Lutheran tradition, and it often provokes resistance in the active attendees of the mainline church. The general cultural rules for proximity are also consciously taken into account and respected, even though the same rules are not as relevant in the Pentecostal tradition. For example, the laying on of hands is a typical and widely used ritual gesture especially for blessing and healing in Pentecostalism (e.g. Cox 1995, 109). However, at the HR prayer clinics, clients are not physically touched without being asked for permission. Even though a prayer clinic allows both men and women to work together and on equal terms, a prayer team member is not supposed to touch a client of the opposite sex at all. This privacy-respecting conduct is explained as taking into account that clients may have personal reasons for not wishing to be touched; these include the possibility that a client may have traumatic memories of sexual abuse, or of other forms of violence that are too painful to be broached.

On the whole, the atmosphere at a prayer clinic is meant to be safe and comfortable and not judgmental—clients may not come back if they are treated aggressively. Approaching holistic healing as a gradual and timeconsuming process, the clinics make clients welcome to visit as many times as they like and feel the need to.

\section{Faith Healing Revisited: Holistic Treatment}

As the name of the HR practice suggests, it is focused on holistic wellbeing. The method used for this purpose is praying for the clients. As the prayer team members put it in order to explain the function of their work, they are "channeling" the power of the Holy Spirit by actively using their "gifts." Strangely enough, the gift of healing was hardly ever mentioned by the interviewees. Rather, they often described situations when they had instead used the gifts of prophecy and words of knowledge while praying for others. Without exception, all interviewees emphasized their role in the healing process as instrumental; they did not want to be identified as "healers." This attitude obviously reflects the internalized HR instructions emphasizing the intercessors' status as mere mediators. 
The meaning and function of the HR, as compared to those of the numerous other Christian organizations which offer corresponding supportive spiritual services, was very clear to the prayer team members whom I met. Even though they were familiar with healing through prayer, they saw intercession at the HR clinics as unique, and as such, a supplement to what is offered to people in other churches and congregations, such as pastoral care. Healing as a holistic process, covering physical as well as psychological and spiritual aspects of the individual, was seen as a potential starting point for the clients' journey towards personal Christian faith. As I asked one of my interviewees how she would define the meaning of the HR prayer clinics in her own words, she responded:

Well, it's like bringing healing and wholeness to people ... anybody can come to be prayed for, you don't have to be a believer. Basically, it is that you could find Jesus Christ as your savior that is the most important thing. Anyway, but God wants to heal you, and it's often so that when you have a chance to experience healing, you also start to look for Jesus in your life, because that's where the help comes from. [...] I take it as a holistic healing. A human being heals only after getting completely whole as the result of becoming a believer, but he or she can feel improvement already here. (IF mgt 2011/014: 2)

When I asked about the main concern of the HR, and whether it was the body or the soul, I often received the answer: both equally. Since people are perceived of as psychosocial beings, the interviewees did not want to separate these elements in their prayer, which is understood as a divine assignment. They often took illness and pain as somatization of unsolved emotional difficulties connected to a nonfunctional spiritual life, "being away from God." Bodily disorders as well as mental and spiritual troubles were seen as being so tightly interwoven that the prayer team members found it difficult to distinguish between them. The most analytical account was given by an active prayer team member who was a neurologist by profession:

Well, we hope, of course, soul. And I wouldn't even like to care for the mind there. I think mental care belongs to the psychiatrists. But naturally, we can pray for it and for healing, but we do not care for the mind at the prayer clinic. And the body ... we don't actually cure anything else either, we just pray, we give prayer service. But perhaps ... we don't really treat the soul either, it doesn't belong to us. We give prayer service and we hope that above all the soul would feel better afterwards. (IF mgt 2011/073: 15) 
He also emphasized the idea of holism and drew a strict line between his professional work at the hospital and what he does at a prayer clinic:

I distinguish between my work and what happens in the Healing Rooms, completely. Here [at the hospital] I strictly represent medical science [...] and there [at the prayer clinic] I see it purely as a spiritual process. So, I don't see here any paradox with regards to my work, but there I practice my faith as I have the legal right to do. And, well, I think that the healing that happens there, it is purely a spiritual thing. (IF mgt 2011/073: 13)

An important theme in Charismatic Christian healing narratives are "wounds of the soul." The term refers to how a variety of unsolved, traumatic earlier experiences can be encapsulated in bodily pains, as well as in mental disorders. "Inner healing" and "becoming whole" are prominent issues in the HR prayer clinics, too, as they are in Charismatic healing in general (cf. Matulevicius 2015). The members recognized, in many cases, problems deriving from clients' early childhood:

Interviewee: There are quite a lot of such troubles that people go through, [like] troubles in their childhood and in their relationship to their mother. There are a lot of such cases. So, they understand now what they missed as a child, because it was as it was. Then we, in a way, help them in that situation $[\ldots]$.

Tuija: That's interesting, the relationship to mother and childhood home, that it comes up like that, as you said. If you think of the age distribution among the clients ... they are people whose parents experienced the war.

Interviewee: Yes, that's right. Then, the culture of parenting was really rough in Finland. I am a specialist in upbringing by profession and I know, considering the emotional development of a child, what the results are, when there is not attention and space for children's emotions, and how the self-esteem, self-confidence is built up. In a way, they have to pick up the pieces, for instance, still at the age of 60 . (IF mgt 2011/051)

Unresolved traumatic experiences constitute an intentional focus in the prayer service. The theme in the interview excerpt above corresponds to what anthropologist Thomas Csordas has analyzed as "healing the memories" in 
his study on Charismatic Catholic healing groups (cf. Csordas 1997, 109). In these groups, the procedure was considerably different, being more verbally interactive, and included pastoral care conversations and visualization of the Virgin Mary as healer of the participants' inner wounds. By contrast, in the Protestant HR rhetoric, it is Jesus who is seen as the gentle supporter and healer (Hovi 2013, 199).

\section{Controversial Border-Crossings}

George Chryssides has pointed out that New Age and Charismatic Christian "holistic health therapies" share certain similarities. Both camps propagate the idea of "making people whole" in ways that cannot be offered by biomedicine. Regarding the differences between the two, in New Age healing, the methods of therapy are much more diverse. The "suppliers" offer a wide range of choices to their clients, not necessarily presupposing any particular belief system. In Christian traditions, "healers" (like the prayer team members in the HR) insist that their work is grounded in the healing power of Jesus Christ, that they are continuing the healing ministry in his name, and that praise and thanks must be offered to him (Chryssides 2000, 66; Neitz 2012).

The HR has been criticized in Finland, above all in Christian circles. Some confrontations take place locally among different Christian communities. As the HR crosses organizational boundaries and disregards conventional modes of operation, the movement is at times perceived as a menace to established forms of Christianity. In many fundamentalist circles, especially in Neo-Charismatic communities, there is aggressive critique of everything with a New Age flavor, even though, or perhaps because, many New Age practitioners propagate the same ideals as those communities, like well-being, a good life, and prosperity-ideals that nevertheless are promoted and understood on different grounds, interpreted with different rhetoric, and framed within another belief system. According to the Charismatic Christian logic, New Age practices are simply viewed as being based on an incorrect and spiritually dubious framework: they are "unbiblical." As an indication of this concern, the HR has even been criticized for representing New Age ideas because it propagates "healing" in its English name, rather than the vernacular terms commonly used in connection with Christian healing practices in Finland. ${ }^{7}$ For the same reason, it has been interpreted as being occult, heretical, and delusional, as well as "too American." Above all, this kind of critique can be found in Christian chat 
forums and blogs on the Internet. ${ }^{8}$ The leaders of the HR in Finland have responded to the criticism by saying that the concept of healing was stolen by New Age thinkers, and that the HR, by contrast, actually wants to rehabilitate the concept by bringing it back to its original biblical meaning:

We think that real healing comes from Jesus, but the New Age movement has stolen it. We want to bring it back to its original context. And another sector where we probably are criticized is that we actually work within the New Age sector. We go to these New Age fairs and happenings and open up prayer clinics there, yeah, and there, more than anywhere, reach the people who are searching! (IF mgt 2011/106: 20)

Meredith McGuire has indicated that the idea of healing, which is so characteristic of New Age thinking, seems to have roots in the spiritual New Thought (or Mind Cure) movement that emerged from transcendentalism and the thinking of Emmanuel Swedenborg, and has also been adopted by several healing-centered Christian organizations like, for instance, Christian Science (McGuire 2008, 133). Such historical links mean very little if anything to Charismatics, but accusations by more established Christian communities against a new Christian movement for representing the New Age movement is typical in situations where new kinds of rhetoric or new forms of action are being introduced, even when the basic biblical message is the same. The present situation, in other words, seems to support Stephen Hunt's observation that there appears to be a widespread need to protect a "symbolic universe of meaning" which underpins the attitude toward other religious groups in terms of boundary maintenance. As suggested by Hunt, this is especially prevalent in Charismatic Christian healing practices (Hunt 2000, 43).

To propagate their interpretation of biblical healing, following Jesus' work as an example, the HR prayer teams introduce their work programmatically at annual New Age events in Finland, the Fair of the Spirit and the Knowledge, and the I Am Fair (Body-Mind-Spirit). These are events at which various New Age practitioners present their services for a couple of days each year. The Finnish leaders of the HR explained that these events are an important forum for the HR, too. They take it as an opportunity to win new followers for Christianity by using the appealing theme of healing, which is a playground for mutual interaction. This supports what Harvey Cox has pointed out; among Charismatics, there is a certain concern, at times even anxiety, about the emergence of non-Christian 
spiritualities. Their answer to the challenge is healing-in its Christian meaning, making a person "whole in Christ." The message of holistic healing is used as a gateway through which new recruits are expected to enter the movement (Cox 2011, xviii). For the HR, one way of branching out has been participation in annual New Age events, thereby offering a Christian alternative to potential "seekers."

Positioning itself as undertaking biblical missionary work fighting nonChristian spirituality as well as secular ways of life, the HR crosses and blurs the borders of traditional Pentecostal evangelization methods. As another example of modernized outreach, in April 2014, the monthly newsletter of the Finnish HR informed its members about the summer activities that would take place while the prayer clinics were taking a break. All regular prayer clinics in the country are closed for a couple of months in summer. During this time, there is, for instance, an HR cruise on the Baltic Sea, which had already become an annual tradition by 2014. During the cruise, there is an HR program for the group, buffet meals, and some free time for shopping or going to the spa, as is customary on Baltic Sea cruises. However, the free time is not only for leisure. It is also an opportunity for "healing the sick on board," which could mean praying silently for passengers, as well as interacting with them (Healing Rooms kuulumiset 2014). This outreach is another example of how the HR has quite radically brought Pentecostal faith healing out of its typical congregational context and revival meetings, and attempted to redefine it as a contemporary Christian well-being practice integrated into modern ways of life.

\section{An Intervention in Post-secular Therapy Culture}

In their theory of the spiritual revolution, Paul Heelas and Linda Woodhead (2005) argue that interest in so-called "subjective life spirituality" is growing faster than for traditional religions. Today, well-being practices that combine Westernized Eastern traditions such as yoga, meditation, life coaching, and mindfulness, are turning into alternatives or supplements to the already established therapy culture, which draws upon more or less scientific-psychological conceptualizations. Historian of religion AnneChristine Hornborg has recognized such holistic healing as a trend in the present decade in Swedish society. According to Hornborg, finding and developing one's inner self with the help of life coaches and lay therapists has become a means of improving one's quality of life in holistic ways (Hornborg 2012, 18). In Finland, the same trend is visible. Spiritually 
inspired therapeutic and coaching practices are based on various traditions from ancient religions and philosophies (such as meditation and yoga based on Buddhist and Vedic traditions) as well as New Age therapies (reiki, angel therapy etc.) or on ideas of modern psychology, for instance neurolinguistic programming and cognitive psychology. The current trend of mindfulness, however, draws on both sources, spiritual and psychological ones.

Similarly, increasing interest in self-awareness and personal growth are not exclusive to alternative, non-Christian, spiritual practices. Sociologist Mary Jo Neitz has pointed out that the Charismatic Catholic Renewal and the psychologically inspired self-awareness movement have a great deal in common. In both movements, people are expected to grow and develop their potential. This is achieved by getting in touch with one's "real self," with God, with a higher consciousness, or with a different reality. In addition, personal growth is seen as a key to social progress (Neitz 2012,20). It can also be interpreted as seeking spiritual authenticity, which is regarded as a prerequisite for holistic health.

The rise of fundamentalist and conservative forms of religiosity during the last couple of decades has been viewed as a set of reactions to the often confusing postsecular trends in religious life: First, conservative religious attitudes have been interpreted as a reaction to globalization, which dissolves the autonomy of national institutions, traditional organizations, and communication systems. Second, they have been viewed as a reaction to cultural flexibility, which blurs the boundaries of membership and involvement in religious life. Finally, they have been considered to be a reaction to the perceived crisis of the patriarchal family (Frisk and Nynäs 2012,57). Despite the apparent paradox, the combination of conservative Charismatic Christianity and postsecular complexity in Finland seems to be functioning quite smoothly. Similar observations have been made in other parts of the world. Many Neo-Charismatic Christian movements and organizations move with ease between the twenty-first-century ideals of globalization, individualism, and even neoliberalism. For example, anthropologist Birgit Meyer has interpreted the global growth of the Prosperity Gospel as an expression of neoliberalism, and its missionary activities as an intentionally globalizing project (Meyer 2010, 114).

However, the HR does not represent the hardcore Prosperity Gospel, with the latter's strong emphasis on material wealth as a sign of God's blessing. Yet, in response to having been criticized as "Americanizing," 
the Finnish HR practice has been purposely rethought and polished so as to be more culturally acceptable. According to the leaders of the Healing Rooms Finland, the movement is "culturized," as they put it, into the secular Lutheran milieu. Ecstatic worship or aggressive proselytization may invite negative reactions and thus be counterproductive. Instead of open evangelization, a carefully considered management technique, strategic planning, customer orientation, and the interest in a new type of interdenominational cooperation have been adopted in order to more easily adapt the HR to neoliberal postsecular Nordic culture. Being a global network with a flexible organization structure that transcends social, organizational, and institutional boundaries between Christian denominations, the HR offers a new kind of involvement that accommodates individual as well as collective activity for lay people (cf. Martikainen et al. 2015, 80-83). For prayer team members, it offers an active role for spiritual selfactualization, and a coherent and democratic community of believers. For clients, a prayer clinic serves as a forum to be used without obligations or commitments. It offers easily accessible, time-efficient, discreet, and individual care. It is free of charge, and nothing is demanded in return. It is simply a place to visit when spiritual care or treatment is needed to solve a problem or to feel better.

\section{Conclusions}

I have presented the HR as a Christian intervention and reaction to postsecular and psychologized culture on the basis of the movement's mode of operation as a spiritual health center. It draws close to the forms and means of contemporary Western customer-oriented therapy culture, which combines the search for well-being and everyday problem-solving with personal spiritual transformations. Unlike counseling based on psychotherapy, the prayer clinic service does not attempt to provide conversational counseling, even though this is sometimes expected by clients. Instead, it is a Christian spiritual practice based on the idea of "channeling" divine power with the help of intercessors' Charismatic gifts in order to heal a person holistically. It is tailored to support people with their, often emotionally difficult, everyday problems involving health and well-being. Even though the ultimate function and purpose of this practice is strictly religious, its actual implementation is carried out in a way that uses modern, popular psychological approaches as well as Christian spirituality. 


\section{Notes}

1. In this chapter, I use several overlapping labels referring to Pentecostal and Charismatic Christianity. By "Pentecostalism" I mean the whole Pentecostal culture in its all diversity, whereas "Classic" or "Traditional" Pentecostalism is used for the movement with roots in the Azusa Street revival at the beginning of the last century. In Finland, Classic Pentecostalism was planted remarkably early, and has attained status as an established church. "Charismatic Christianity" refers to the accentuated role and meaning of the "Gifts of the Holy Spirit" in everyday religious life, as well as a current in Christianity—among Protestants and Catholics—often represented by layled activities within established churches. With "Neo-Charismatic" and "Neo-Pentecostal," I refer to the trend of independent congregations and churches that emerged in the United States as a result of Third Wave Pentecostalism during the 1980s and ' 90 s, often characterized by doctrinal emphasis on health and material prosperity (cf. Anderson 2010, 19-20). However, in Finland, Neo-Pentecostalism has a slightly different meaning, pointing specifically to the renewal within the Pentecostal Movement in the 1970s, and its impact on activities within the Evangelical Lutheran Church later on. "Neo-Charismatic Movement" refers to the field of independent congregations that has appeared since the 1990s. In spite of these national nuances, I use these labels as more or less synonymous in this chapter. Moreover, "fundamentalism" is used to denote a meaning system that relies exclusively upon a sacred text, in this case literalistic interpretation of the Bible, whereas a movement labeled as "conservative" emphasizes reluctance to accept reform and innovation.

2. The study of the Healing Rooms at hand was funded by the Academy of Finland (2011-2013) and was simultaneously one of the case studies of the Center of Excellence project Post-secular Culture and Changing Religious Landscape in Finland 2010-2014 at Åbo Akademi University in Turku.

3. As Finland was a part of Sweden until 1809 , there was a state church tradition there as well, and the Lutheran Church held that position until 1870. The close ties between church and state started to loosen up in the nineteenth century because of European ideological influences: the Pietist revival movements and liberalism (Ketola 2008, 61). This means that the separation between church and state had already taken place in Finland before it gained national independence, during its period of autonomy within the Russian regime (1809-1917). The corresponding separation of church and state in Sweden was carried out only 130 years later, in the year 2000 (ELC 2017).

4. A recent attempt to classify the Third Wave-inspired communities not historically but functionally is made by Jessica Moberg (2015).

5 . The term "client" may sound misleading in this context because it is usually understood to be connected with economic exchanges. Even though HR services are based upon voluntary work and are free of charge, I refer to the 
visitors as "clients" because most of the members of the prayer teams in Finland do so. The Finnish word asiakas literally means "a client" in English. The interviewed prayer team members did not have any problem with the term, even though it has commercial connotations in other contexts. They also used the word "customer-oriented" while describing the principles of their practice. Occasionally, HR clients are called by other names, such as "attenders" / "visitors" (küvijüt) or "those who are prayed for" (rukoiltavat).

6. The interview material compiled by author is archived at Åbo Akademi University. The reference after quotations signifies the archived unit.

7. Apparently, HR is referred to by the same name all over the world and is not translated into the vernacular.

8. Likewise, the American Neo-Pentecostal evangelist David Herzog, who held a set of healing meetings at the Olympic Stadium of Helsinki in July 2014 , raised the same kind of critique, even in the leading national newspaper Helsingin Sanomat (Sippola 2014).

\section{REFERENCES}

Åbo Akademi University. Post-secular Culture and Changing Religious Landscape in Finland 2010-2014. http://web.abo.fi/fak/hf/relvet/pccr/. Accessed 23 Apr 2015.

Anderson, Allan. 2004. An Introduction to Pentecostalism: Global Charismatic Christianity. Cambridge: Cambridge University Press.

- 2010. Varieties, Taxonomies, and Definitions. In Studying Global Pentecostalism: Theories and Methods, ed. Allan Anderson, Michael Bergunder, André Droogers, and Cornelis van der Laan, 13-29. Berkeley: University of California Press.

Bahram, Masoumeh. 2013. Habermas, Religion, and Public Life. Journal of Contemporary Religion 28: 353-368.

Beyer, Peter. 2003. De-centring Religious Singularity: The Globalization of Christianity as a Case in Point. Numen 50 (4): 357-386.

Brown, Candy Gunther. 2011. Introduction: Pentecostalism and the Globalization of Illness and Healing. In Global Pentecostal and Charismatic Healing, ed. Candy Gunther Brown, 3-26. Oxford: Oxford University Press.

Chryssides, George. 1999. Exploring New Religious Movements. London: Continuum International Publishing.

- 2000. Healing and Curing: Spiritual Healing, Old and New. In Healing and Religion, ed. Marion Bowman, 59-68. Enfield Lock: Hisarlik Press.

Cox, Harvey. 1995. Fire from Heaven. The Rise of Pentecostal Spirituality and the Reshaping of Religion in the Twenty-First Century. Reading: Addison-Wesley Publishing Company. 
2011. Foreword. In Global Pentecostal and Charismatic Healing, ed. Candy Gunther Brown, xvii-xxxi. Oxford: Oxford University Press.

Csordas, Thomas J. 1997. The Sacred Self: A Cultural Phenomenology of Charismatic Healing. Berkeley: University of California Press.

De Vos, Jan. 2012. Psychologisation in Times of Globalisation. Hove/New York: Routledge.

Evangelical Free Church of Finland (EFCF). 2017. http://www.svk.fi. Accessed 23 Nov 2017.

Evangelical Lutheran Church of Finland (ELC). 2017. http://evl.fi/. Accessed 23 Nov 2017.

Frisk, Liselotte, and Peter Nynäs. 2012. Characteristics of Contemporary Religious Change: Globalization, Neoliberalism, and Interpretative Tendencies. In Postsecular Society, ed. Peter Nynäs, Mika Lassander, and Terhi Utriainen, 47-70. New Brunswick: Transaction Publishers.

Habermas, Jürgen. 2006. Religion in the Public Sphere. European Journal of Philosophy 14: 1-25.

Healing Rooms. 2014. Healing Rooms kuulumiset, huhtikuu. HR monthly newsletter by e-mail, April, 2014.

Healing Rooms Estonia. 2017. http://www.healingrooms.ee/. Accessed 23 Nov 2017.

Healing Rooms Finland. 2017. http://www.healingrooms.fi/. Accessed 23 Nov 2017.

Healing Rooms Sweden. 2017. http://www.healingrooms.se/. Accessed 23 Nov 2017.

Heelas, Paul, and Linda Woodhead. 2005. The Spiritual Revolution: Why Religion is Giving Way to Spirituality. Malden: Blackwell.

Hornborg, Anne-Christine. 2012. Coaching och lekmannaterapi: en modern väckelse? Stockholm: Dialogos.

Hovi, Tuija. 2009. Suomalainen uuskarismaattisuus. Teologinen AikakauskirjaTeologisk tidskrift 114: 66-73.

- 2012. Clinical Services Instead of Sermons. In Post-secular Religious Practices, Scripta Instituti Donneriani Aboensis, ed. Tore Ahlbäck, vol. 24, 128-144. Åbo: Donnerska institutet.

- 2013. Meanings of Healing: Experiences of Prayers at the Christian Healing Rooms Prayer Service in Finland. In Constructs of Meaning and Religious Transformation, ed. Herman Westerink, 185-205. Göttingen: V \& R Unipress.

Hovi, Tuija, and Anna Haapalainen. 2015. Omaehtoinen yhteisöllisyys 2000luvun kristillisyydessä. In Kansanuskosta nykypäivän henkisyyteen, ed. Pasi Enges and Kirsi Hänninen, and Tuomas Hovi. 158-187. Turku: Turun yliopisto.

Hunt, Stephen. 2000. The 'Problem' with Alternative Medicines: Some Dynamics of Boundary Maintenance Amongst Neo-Pentecostal Healing Groups. In 
Healing and Religion, ed. Marion Bowman, 35-57. Enfield Lock: Hisarlik Press.

Ihanus, Juhani. 2005. Järjen ä̈̈nestä minäkertomuksiin. Psyyken ja psykoterapioiden muodonmuntoksia. Helsinki: Yliopistopaino.

Ketola, Kimmo. 2007. Spiritual Revolution in Finland? Evidence from Surveys and the Rates of Emergence of New Religions and Spiritual Organizations. Nordic Journal of Religion and Society 19: 29-39.

- 2008. Uskonnot Suomessa: Käsikirja uskontoibin ja uskonnollistaustaisiin liikkeisiin. Kirkon tutkimuskeskuksen julkaisuja 102. Tampere: Kirkon tutkimuskeskus.

Kivivuori, Janne. 1991. Psykokulttuuri: Sosiologinen näkökulma arjen psykologisoitumisen prosessiin. Helsinki: Hanki ja jää.

- 1996. Psykopolitiikka: Paljastava psykologia suomalaisen ybteiskunnallisen keskustelun perinteenä. Helsinki: Hanki ja jää.

- 1999. Psykokirkko: Psykokulttuuri, uskonto ja moderni ybteiskunta. Helsinki: Gaudeamus.

Klassen, Pamela E. 2011. Spirits of Protestantism: Medicine, Healing, and Liberal Christianity. Berkeley: University of California Press.

Laitinen, Susanne. 2013. Klinikkaterveisiä maailmalta. Kristillisen rukousklinikan tiedotuslebti Healing Rooms, 2/2013. (Greetings from international prayer clinics. - Newsletter of the Christian Prayer Clinic Healing Rooms).

Martikainen, Tuomas, Måns Broo, Tuija Hovi, Marcus Moberg, and Terhi Utriainen. 2015. The Changing Forms of Religious Organisations. In On the Outskirts of "the Church": Diversities, Fluidities and New Spaces of Religion in Finland, ed. Peter Nynäs, Ruth Illman, and Tuomas Martikainen, 73-87. Zürich: LIT.

Matulevicius, Saulius. 2015. From Pentecost to 'Inner Healing': Religious Change and Pentecostal Developments in the Post-socialist Lithuanian Catholic Milieu. Approaching Religion 5: 67-78.

McGuire, Meredith B. 2008. Lived Religion. Faith and Practice in Everyday Life. Oxford: Oxford Universtity Press.

Meyer, Birgit. 2010. Pentecostalism and Globalisation. In Studying Global Pentecostalism: Theories and Methods, ed. Allan Anderson, Michael Bergunder, André Droogers, and Cornelis van der Laan, 113-130. Berkeley: University of California Press.

Moberg, Jessica. 2015. Pentecostal Currents and Individual Mobility: Visiting Church Services in Stockholm County. Approaching Religion 5: 31-43.

Moberg, Marcus, Kennet Granholm, and Peter Nynäs. 2012. Trajectories of Postsecular Complexity: An Introduction. In Post-secular Society, ed. Peter Nynäs, Mika Lassander, and Terhi Utriainen, 1-25. New Brunswick: Transaction Publishers.

Neitz, Mary Jo. 2012. The Charismatic Renewal and the Culture of Narcissism. In Fundamentalism and Charismatic Movements: Charismatic and Conversion 
Movements, Critical Concepts in Religious Studies, ed. Humeira Iqtidar and David Lehmann, vol. 3. London: Routledge.

Nynäs, Peter, Ruth Illman, and Tuomas Martikainen. 2015. Rethinking the Place of Religion in Finland. In On the Outskirts of 'the Church': Diversities, Fluidities and New Spaces of Religion in Finland, ed. Peter Nynäs, Ruth Illman, and Tuomas Martikainen, 11-28. Zürich: LIT.

Palmu, Harri, Hanna Salomäki, Kimo Ketola, and Kati Niemelä. 2015. Haastettu Kirkko: Suomen evakelisluteralainen kirkko vuosina 2008-2011. http://sakasti. evl.fi/sakasti.nsf/0/.../\$FILE/Haastettu\%20kirkko.pdf. Accessed 8 Jan 2016. Pentecostal Church of Finland (PCF). 2017. http://www.suomenhelluntaikirkko. fi/. Accessed 23 Nov 2017.

Pietikäinen, Petteri. 2000. Psykokultuurin kritiikki. Tieteessä tapahtuu 18(8). http://journal.fi/tt/issue/view/4121. Accessed 20 Apr 2017.

PingstFi. Info om de finlandssvenska pingsförsamlingarna 2017. https://pingstfi. blog/. Accessed 23 Nov 2017.

Siltala, Juha. 1992. Suomalainen ahdistus: buoli sielun pelastumisesta. Helsinki: Otava.

- 1994. Miehen kunnia: Modernin miehen taistelu häpeää vastaan. Helsinki: Otava.

Sippola, Jussi 2014. Ihmeitä lupaileva saarnaaja ei ota vastuuta puheistaan. Helsingin Sanomat, July 27.

Utriainen, Terhi, Tuija Hovi, and Måns Broo. 2012. Combining Choice and Destiny: Identity and Agency Within Post-secular Well-Being Practices. In Postsecular Society, ed. Peter Nynäs, Mika Lassander, and Terhi Utriainen, 187216. New Brunswick: Transaction Publishers.

Open Access This chapter is distributed under the terms of the Creative Commons Attribution 4.0 International License (http://creativecommons.org/ licenses/by/4.0/), which permits use, duplication, adaptation, distribution and reproduction in any medium or format, as long as you give appropriate credit to the original author(s) and the source, provide a link to the Creative Commons license and indicate if changes were made.

The images or other third party material in this chapter are included in the chapter's Creative Commons license, unless indicated otherwise in a credit line to the material. If material is not included in the chapter's Creative Commons license and your intended use is not permitted by statutory regulation or exceeds the permitted use, you will need to obtain permission directly from the copyright holder.

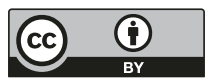

